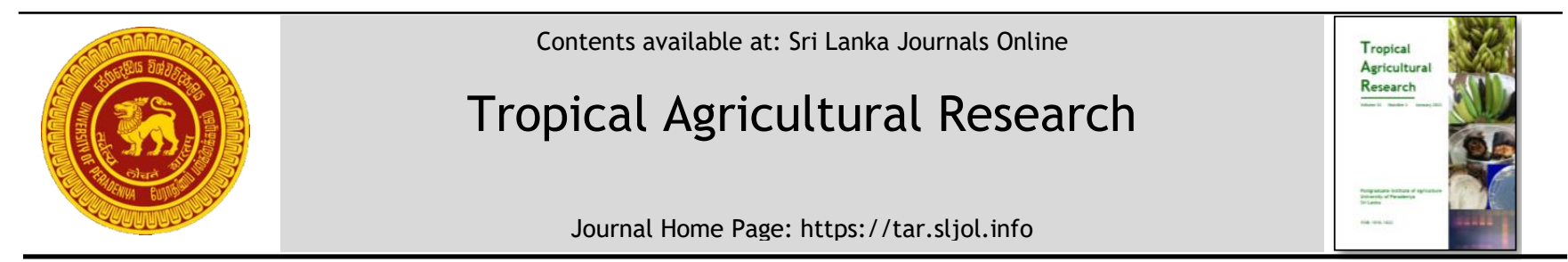

\title{
Pre-Harvest Finger Rot of Cavendish Banana (Musa acuminata) Reported from Moneragala and Badulla Districts, Sri Lanka: Identification and Confirmation of Pathogenicity of the Causal Agent
}

\author{
W.M.P. Kalpani ${ }^{1}$, D.M. De $\operatorname{Costa}^{1 *}$ and T.R. Haputhantri ${ }^{2}$ \\ ${ }^{1}$ Postgraduate Institute of Agriculture, University of Peradeniya, Peradeniya, Sri Lanka. \\ ${ }^{2}$ Dole Lanka (Pvt.) LTD., 12 th Floor, Parkland Building, No. 33, Park Street, Colombo 2, Sri Lanka.
}

\section{ARTICLE INFO}

\section{Article history:}

Received: 16 July 2020

Revised version received: 24 October 2020

Accepted: 05 November 2020

Available online: 1 January 2021

\section{Keywords:}

Banana

Dickeya dadantii

Pathogenicity

Soft rot

\section{Citation:}

Kalpani, W.M.P., De Costa, D.M. and Haputhantri, T.R. (2021). Pre-Harvest Finger Rot of Cavendish Banana (Musa acuminata) Reported from Moneragala and Badulla Districts, Sri Lanka: Identification and Confirmation of Pathogenicity of the Causal Agent. Tropical Agricultural Research, 32(1): 27-38.

DOI: http://doi.org/10.4038/tar.v32i1.8439

Kalpani, W.M.P.

https://orcid.org/0000-0003-3404-1356

\section{ABSTRACT}

The present study was conducted to identify and confirm the pathogenicity of the causal agent of a wet finger rot of Cavendish banana, a newly reported pre-harvest disease in commercial plantations in Moneragala and Badulla districts of Sri Lanka. Bacterial species were isolated from banana fingers at three stages of symptom development: initial, middle, and late. Isolated bacterial colonies were inoculated to healthy and mature banana fingers by two methods, namely peel and pulp inoculation, to confirm the pathogenicity by Koch's postulates. Re-isolated bacterial isolates from inoculated banana fingers showing typical symptoms were identified by biochemical tests and subjected to PCR amplification using universal primers of bacteria, B27F/1492R. Subsequent DNA sequencing of the PCR products and homology search identified the pathogen as a strain of Dickeya dadantii. Phylogenetic analysis with selected Dickeya spp. sequences available in databases identified that the D. dadantii strain of the present study groups with $D$. dadantii 3937 (CP002038.1), of which the complete genome has been sequenced. Cross infection studies revealed that $D$. dadantii isolate is more virulent on banana variety Anamalu than on Cavendish banana in terms of days taken to develop the symptoms. The findings identified the causal agent of wet finger rot of banana in the present study as a strain of $D$. dadantii and confirmed its pathogenicity.

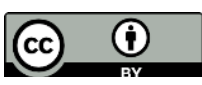

*Corresponding author : devikadecosta@gmail.com 


\section{INTRODUCTION}

Banana (Musa acuminata) is one the oldest and worldwide popular fruits with high nutritional value. As a tropical country, Sri Lanka has the optimum climatic conditions for banana cultivation throughout the year, hence can provide a continuous supply to fulfill the consumer demand of the fruit. Several varieties of $M$. acuminata are widely cultivated all over the island in large, medium, and small scale plantations and in homegardens. Nearly half of the national production of banana is provided from Kurunegala, Rathnapura, and Moneragala districts of Sri Lanka. It is recorded that nearly 60,000 ha under banana cultivation, annually produces approximately $780,000 \mathrm{MT}$ with an average yield of $13 \mathrm{MT} / \mathrm{ha}$ (Hathrusinghe et al., 2012). Out of the total land area under banana cultivation, 13,000 ha are used for plantains (i.e. cooking type banana) and the rest is under the cultivation of dessert type banana (Hathrusinghe et al., 2012). However, production data of the commodity is at underestimation due to the contribution of extensive homegarden level banana production.

With the introduction of Cavendish type banana, Sri Lankan export market was expanded due to the higher demand in European, American, Middle Eastern and Japanese markets and entering of world leading banana exporters into the industry. Sri Lanka earned 14,934,000 US dollars by exporting 17,036,266 $\mathrm{kg}$ of banana in 2018 (EDBSL, 2019). However, still the country is exporting only $5 \%$ of its total banana production (Perera et al., 2015).

As a biotic threat to the local and export market of banana, a new disease has been noticed in several Cavendish (AAA genome group) plantations in Moneragala and Badulla Districts over the last few years. Approximately, 3\% of yield loss has been estimated in 120 ha of cultivated area of Cavendish banana due to the disease. Yield loss due to the newly-noticed disease is nearly constant throughout the year with a slight increase after rainy periods.

Based on the nature of the field symptoms, the disease could be identified as a pre-harvest soft rot of banana fingers. Several cases of bacterial soft rots of banana caused by Pectobacterium carotovorum have been reported in Korea, India and Iran (Hassanzadeh, 1990; Snehalatharani and Khan, 2010) and an outbreak of bacterial soft rot of banana caused by Dickeya zeae has been reported in Guangzhou, China in 2009 (Lin et al., 2010). Banana sheath rot is another soft rot caused by
Dickeya dadantii and has been reported in China since in 2011 (Liu et al., 2016).

However, the symptoms of newly reported disease in the banana plantations in Sri Lanka do not match exactly with the available literature of soft rot diseases of banana. Therefore, identification based on field symptoms is a difficulty. When analysed the nature of the symptoms developed on banana fingers, the locally-emerged disease could be hypothesised as an infection of an enterobacterial bacterium such as Erwinia spp., Dickeya spp. or Pectobacterium spp., However, accurate identification of the causal organism and confirmation of pathogenicity are essential prerequisites to introduce effective management measures to secure the Sri Lankan banana industry from the newly-reported disease.

Therefore, the present study was focused on elucidating the steps of disease development and isolation, and identification and confirmation of pathogenicity of the causal organism of banana finger rot reported from banana plantations in some districts of Sri Lanka.

\section{MATERIALS AND METHODS}

\section{Collecting information on disease development under field conditions and yield loss}

Sequential steps of finger rot development were identified with photographs and yield loss experienced over a period of 52 weeks was recorded in a commercial Cavendish banana plantation (i.e. Dole Lanka) in Mahiyangana of Badulla district. Rainfall data over a period of one year (July 2019 to July 2020) was recorded.

\section{Sample collection and isolation of pathogens}

Banana fruits showing typical symptoms at three disease developmental stages (i.e. initial, middle and late) (Figure 1) were collected from Dole Lanka plantations in Mahiyangana, Badulla district.

Triangular pieces, having approximately $3 \mathrm{~mm}$ vertices were excised from the peel of symptomatic banana fingers, surface sterilized using a 1\% clorox solution by dipping for $2 \mathrm{~min}$ and rinsing thrice with sterilized distilled water then blotted on sterilized tissue papers and placed on Potato Dextrose Agar (PDA) medium. As another method of isolation of the pathogens, symptomatic banana fingers were cross sectioned using sterilized scalpel and a loop full of rotted pulp was placed directly on PDA medium without any sterilization. 
Plates were incubated at $30{ }^{\circ} \mathrm{C}$ for $24-48$ hours. Consistently resulted in bacterial cultures were purified by streaking on Nutrient Agar medium (NA).

\section{Identification of bacterial cultures by conventional methods}

Bacterial colony morphology on NA medium was recorded and young cultures of each isolate were subjected to Gram's staining and 3\% $\mathrm{KOH}$ test to determine the Gram status and to identify the cell morphology. Each isolate was spotted on to Crystal Violet Pectate (CVP), a semi selective medium to identify pectolytic bacteria through their cavity forming ability.

\section{Confirmation of pathogenicity}

Healthy-looking, blemish free and, unripe Cavendish banana fingers collected from fields of Mahiyangana were used to confirm pathogenicity following standard Koch's rules. Each bacterial isolate which were consistently-obtained from the three developmental stages were separately inoculated to banana fingers by two methods, namely peel inoculation and pulp inoculation. To this end, banana fingers which were surface sterilized with $70 \%$ ethanol were injected with 0.1 $\mathrm{mL}$ of each bacterial suspension having a cell concentration of $1 \times 10^{8} \mathrm{CFU} / \mathrm{mL}$, using a $1 \mathrm{~mL}$ syringe. Banana fingers under control treatment were inoculated with sterile distilled water and all inoculated fingers were incubated separately in a humid chamber at room temperature till symptom development. Each treatment combination (bacterial isolate $\mathrm{x}$ method of inoculation) was maintained with four replicates. Re-isolation of the bacterial isolates was done from fingers which developed symptoms.

\section{Pathogenicity Testing on Banana Variety Anamalu}

Pathogenicity of the bacterial isolates was also tested on another banana cultivar Anamalu which is on the same genome group (AAA) and one of the popular dessert banana varieties in Sri Lanka. The inoculation and incubation was conducted as described earlier for Cavendish banana.

\section{Molecular Identification}

Three bacterial isolates, confirmed their pathogenicity through Koch's postulate were cultured separately in Nutrient Broth (NB) medium at $37{ }^{\circ} \mathrm{C}$ for overnight in a shaking water bath at
$100 \mathrm{rpm}$. Total DNA was extracted from the bacterial cells using Chen method (Chen and Kuo,1993), observed on $0.8 \%$ agrose gel to check the integrity and determined the DNA quality and quantity by spectrophotometrically (Nanospec, Shimadzu, Japan).

Polymerase Chain Reaction (PCR) was performed using Bio-Rad thermocycler, with a bacterial universal primer pair (B27F/1492R, 5'AGAGTTTGATCCTGGCTCAG-3' and 5'GGTTACCTTGTTACGACTT-3'), which amplifies bacterial 16s rDNA intergenic spacer region (Frank et al., 2008). PCR reaction mixture contained 25.0 $\mu \mathrm{l}$ master mix, $4.0 \mu \mathrm{l} \mathrm{MgCl}_{2}, 2.0 \mu \mathrm{lBSA}, 5.0 \mu \mathrm{l}$ of each primers and template DNA and volume was adjusted to $50 \mu \mathrm{l}$ with nuclease free water. PCR reaction conditions of $94{ }^{\circ} \mathrm{C}$ for $45 \mathrm{~s}, 54{ }^{\circ} \mathrm{C}$ for 1 min, and $72{ }^{\circ} \mathrm{C}$ for 1 min were maintained for 35 cycles, proceed by an initial denaturing step at 94 ${ }^{\circ} \mathrm{C}$ for $5 \mathrm{~min}$ and followed by an extension step at $72{ }^{\circ} \mathrm{C}$ for 7 minutes. Amplified PCR products were analysed by electrophoresis on $2 \%$ agarose gel.

Obtained PCR products were sequenced at the Department of Molecular Biology and Biotechnology, Faculty of Science, University of Peradeniya with respective primers. The sequence was analysed with the BLAST tool given by the National Center for Biotechnology Information (NCBI) database. Re-isolated bacterial isolates from the Koch's postulate were also subjected to above PCR conditions and sequenced for confirmation of pathogenicity at molecular level.

\section{Phylogenetic Analysis}

The 16s rDNA sequence of the isolate $A_{1}$ (the bacterium confirmed to be the pathogen and best matched with Dickeya dadantii) was subjected to BLAST analysis against sequences in the NCBI. Several selected Dickeya species including top hits and several soft rot causing Dickeya spp. available in NCBI GenBank were used for phylogenetic analyses (https://www.ncbi.nlm.nih.gov/ genbank) (Table 1).

The preliminary automatic alignment was generated with the CLUSTAL $W$ with 15 gap penalty. The Neighbor Joining (NJ) tree was inferred from the align sequences using Molecular Evolutionary Genetics Analysis Program (MEGA) version 7.0 (Kumar et al., 2016) with 1000 bootstrap value. 
Table 1: Sequences of Dickeya sp. used for phylogenetic analysis and GenBank references

\begin{tabular}{lc}
\hline \multicolumn{1}{c}{ Species Used } & GenBank Accession Number \\
\hline Dickeya dadantii pep2 & KT833226 \\
Dickeya dadantii KAR15 & KR054977 \\
Dickeya dadantii SUPP3081 & LC029911 \\
Dickeya dadantii NCPPB898 & KY231142 \\
Dickeya dadantii 3937 & KU758911 \\
Dickeya dadantii subsp. dieffenbachiae LMG25992 & NR118134 \\
Dickeya dadantii subsp. dieffenbachiae & JX575747 \\
Dickeya dadantii subsp. dieffenbachiae CFBP2051 & NR041924 \\
Dickeya diyanthicola SUPP2565 & AB489902 \\
Dickeya diyanthicola MAFF311533 & LC043147 \\
Dickeya diyanthicola SUPP2546 & LC042604 \\
Dickeya chrysanthemi NCCPPB3533 & KC844750 \\
Dickeya chrysanthemi NCCPPB1861 & KC844731 \\
Dickeya paradisiaca CFBP3699 & KC844738 \\
Dickeya paradisiaca CFBP 3477 & AF520710 \\
Dickey zeae NCPPB2538 & KC844739 \\
Dickey zeae NCPPB2339 & KC844740 \\
Dickey zeae CFBP6466 & KC844741 \\
\hline
\end{tabular}

\section{RESULTS AND DISCUSSION}

\section{Stages of disease development and yield loss}

The symptoms of the fingers became visible when the bunch was at 8-10 weeks after emergence. At the initial stage of the symptom development, a water soaked patch/oil stain was visible on the peel (Figure 1a). Gradually, it expanded over the peel while turning the older part of the patch in to black colour (Figure 1b). Then the black coloured area expanded over the finger leaving a clear necrotic margin around and this stage was considered in the study as the middle stage (Figure 1c). Subsequently, the rot developed on the entire finger and pulp became soft as a watery liquid with characterized unpleasant odour (late stage) (Figure 1d). Usually, it takes 3 or 4 days to reach from initial to late stage.

Normally, infected banana bunch bears 3 or 4 hands including 1-3 infected fingers in each. In rare cases, infected bunch bears about 8-10 hands including a few fingers with symptoms (Figure 2a and Personal Communication by T.M.M.S. Thennakoon and T.R. Haputhantri, Dole Lanka PVT (LTD)). Over the period of March 2019 and February 2020, out of the banana hands harvested from a field in Mahiyangana, Badulla district, percentage of hands discarded due to finger rot ranged between 0.91 and 7.92. For export purposes, the whole hand will be considered as a waste even if there is only one infected finger/hand. However, any abnormal appearance could not be observed in leaves, petioles, pseudostem or rhizome of the infected banana plants (Figures 2b, 2c, 2d and 2e).

Yield loss due to finger rot over a one-year period is shown along with the rainfall received during that period (Figure 3). It was evident that the yield loss due to finger rot was higher after a rainy period and the yield loss was minimum after a dry spell. As shown in Figure 3, yield loss was visible after a one-month period of the rainfall data. The average yield loss due to this disease has been estimated as 104 tons per year. 
(a)

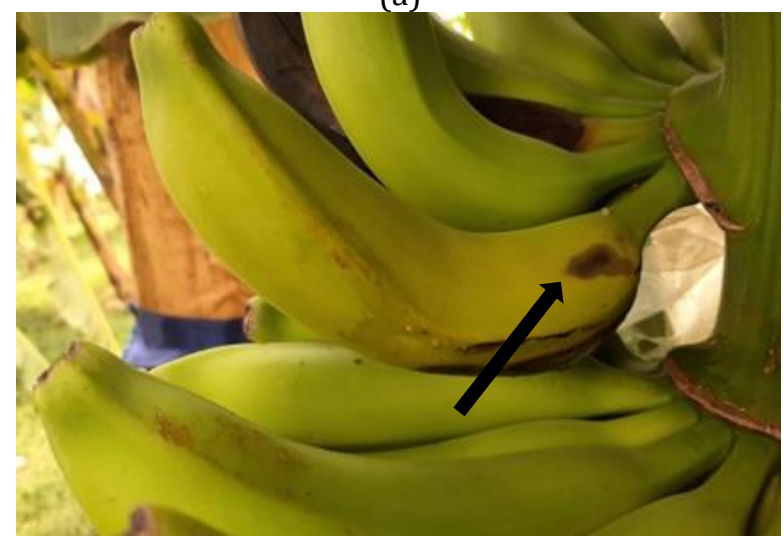

(c)

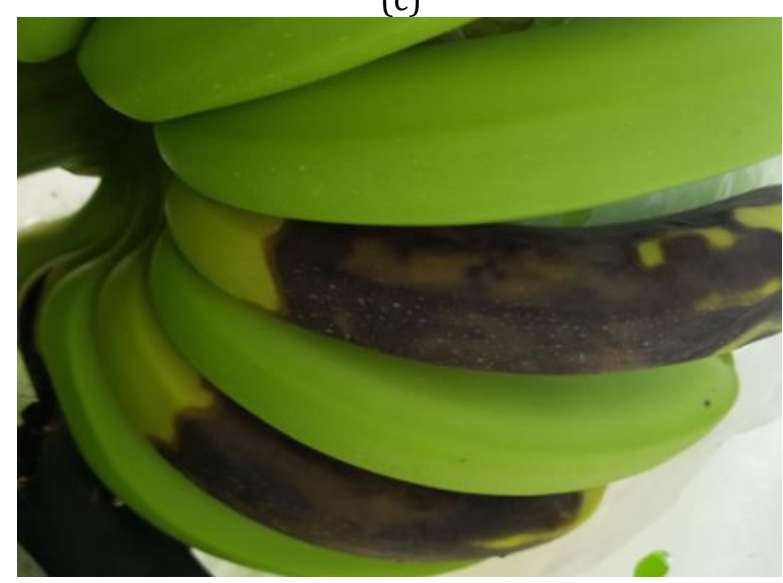

(b)

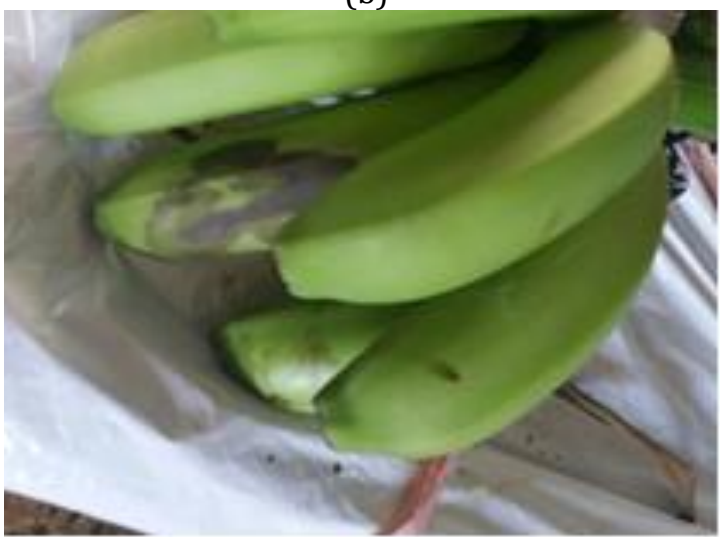

(d)

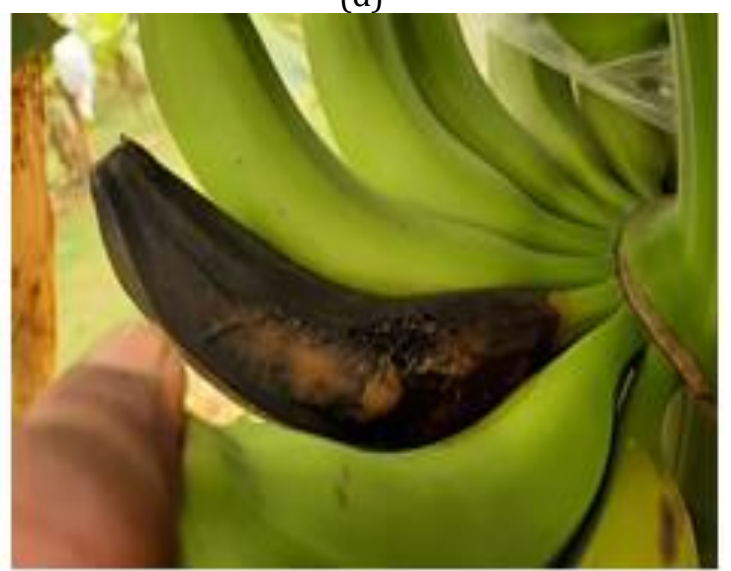

Figure 1: Different stages of symptom development of finger rot of banana. Initiation of the symptom (A), early stage of the symptom development (B), middle stage of the symptom development (C), late stage of the symptom development (D).

As there are several bacterial soft rot diseases reported from many parts of the world (Hassanzadeh, 1990; Snehalatharani and Khan, 2010; Liu et al., 2016; Samson et al., 2005), knowledge on the sequence of symptom development and characteristic symptoms of the finger rot disease reported in Sri Lanka would be useful for disease identification and management, especially based on field symptoms.

\section{Characteristics of the Isolated Bacterial Colonies}

Bacterial colonies consistently-isolated from banana fingers with symptoms at initial, middle and late stages are summarized in Table 2.

Bacterial isolate $\mathrm{A}_{1}$ was present with the initial and middle stage of the symptom development and it was isolated from both peel and pulp tissues. When the symptoms reached the middle stage, two additional types of bacteria $\left(\mathrm{B}_{1}\right.$ and $\left.\mathrm{C}_{1}\right)$ were isolated. At the late stage, $B_{1}$ bacterial isolate could be isolated from peel and pulp tissues but at initial stage $B_{1}$ and $C_{1}$ isolates were not present in peel and pulp tissues.

Colony morphology, cell shape and the results given for the biochemical assays by the three bacterial isolates are given in Table 3 and Figure 4.

Gram staining and culturing on selective media are common conventional methods used for identification of plant pathogenic bacteria. Based on the nature of the symptoms of the banana finger rot, an involvement of a soft rot causing, pectolytic bacterium was expected to be the causal organism of the disease. 

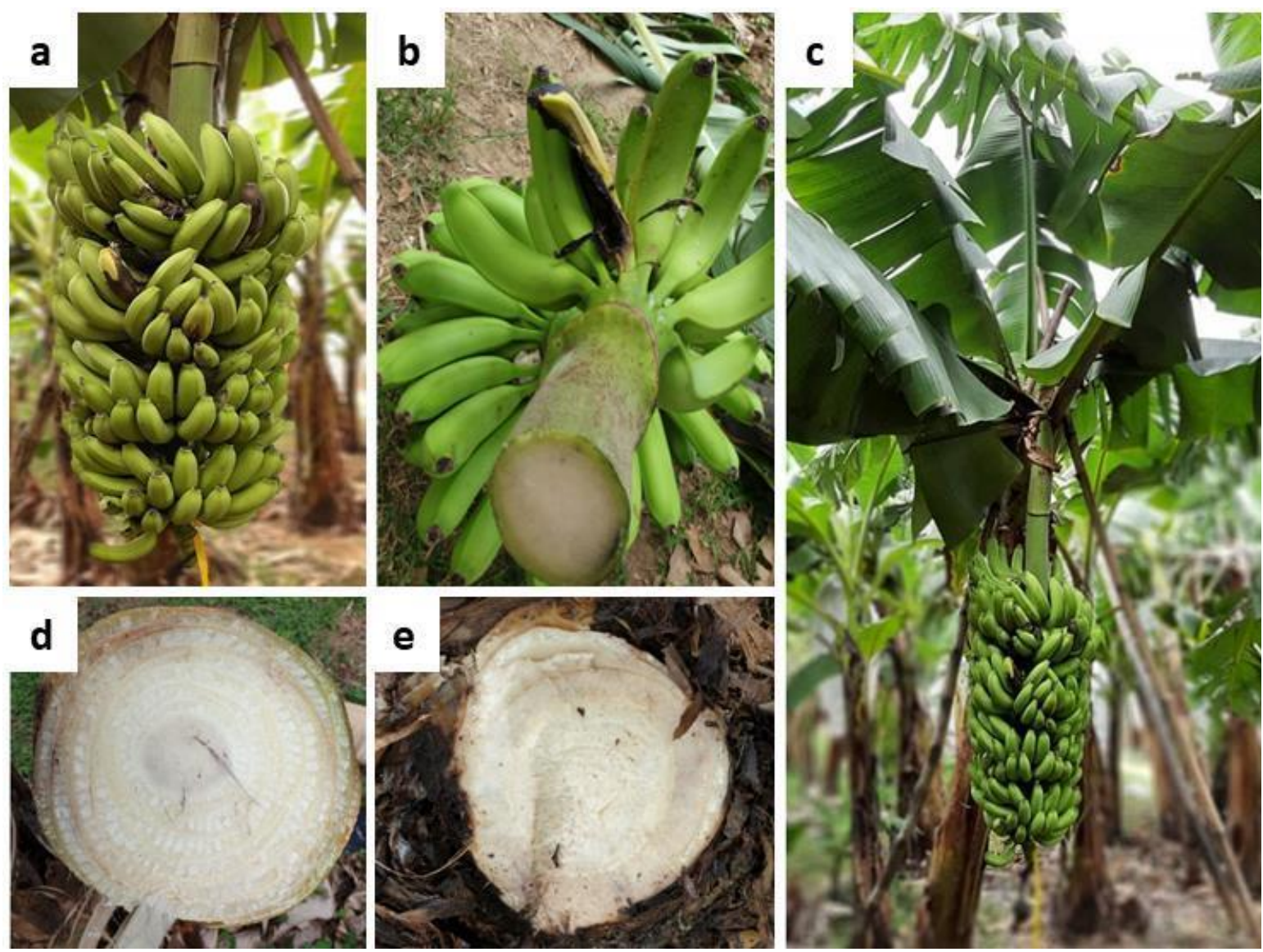

Figure 2: Field observations of different parts of banana tree infected with finger rot. A bunch at mature stage showing necrotic patches on a few fingers (a), cross section of the peduncle of a banana bunch with infected fingers (b), a banana plant bearing a bunch having infected fingers with healthy looking leaves (c), cross section of the pseudostem of an infected tree (d), and cross section of a rhizome of an infected tree (e).

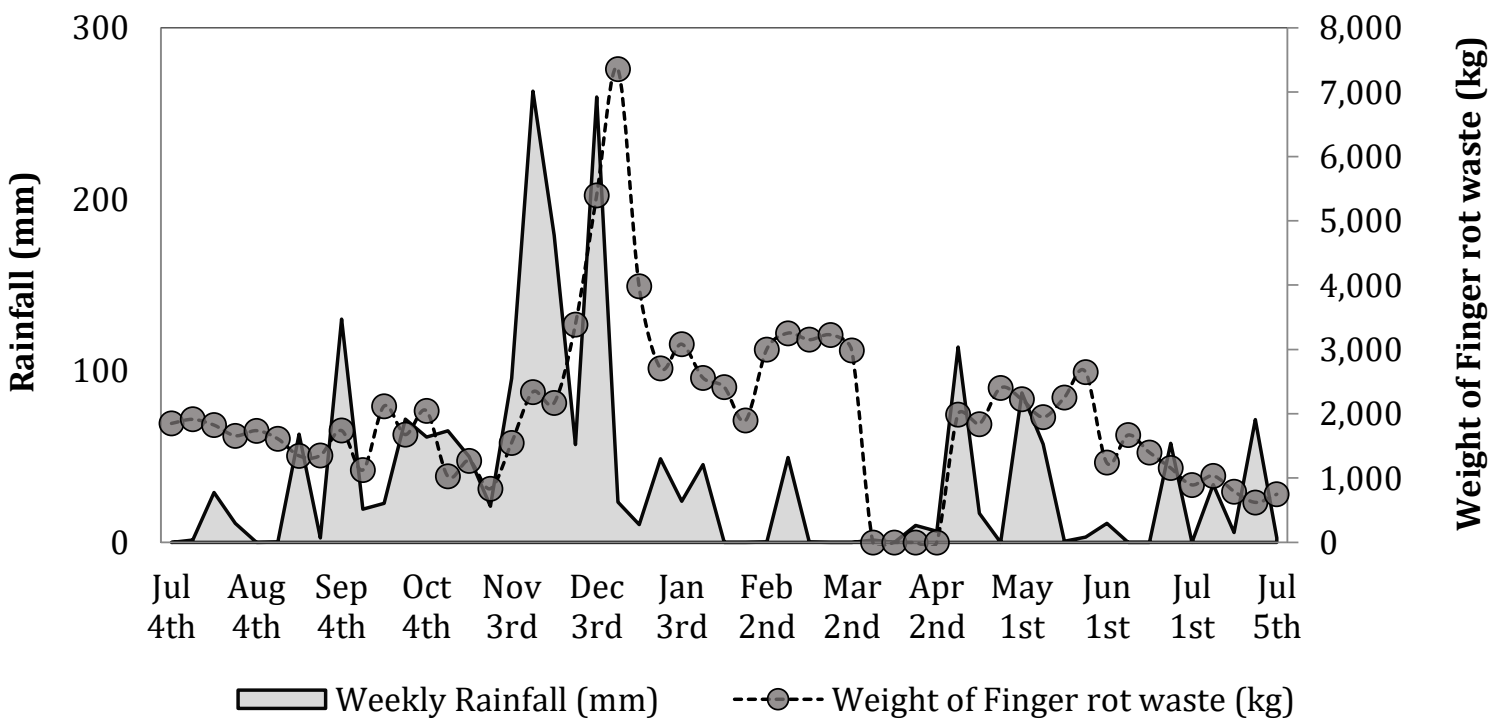

Figure 3: Weight of banana yield loss due to finger rot over a period of one year and the weekly rainfall received during the recording period, Dole Lanka farm, Mahiyangana. 
Table 2: Consistently-isolated bacterial colony types from different symptom developmental stages of banana finger rot.

\begin{tabular}{llll}
\hline Sample No. & Stage & Tissue type & $\begin{array}{c}\text { Code of isolate (Percentage occurrence of the } \\
\text { bacterial isolate from the isolations made) }\end{array}$ \\
\hline 01 & Initial & Peel & $\mathrm{A}_{1}(100 \%)$ \\
& Pulp & $\mathrm{A}_{1}(100 \%)$ \\
& Middle & Peel & $\mathrm{A}_{1}(50 \%) \mathrm{B}_{1}(25 \%), \mathrm{C}_{1}(25 \%)$ \\
& Pulp & $\mathrm{A}_{1}(100 \%)$ \\
& Peel & $\mathrm{B}_{1}(100 \%)$ \\
& Late & Pulp & $\mathrm{B}_{1}(100 \%)$ \\
& & Peel & $\mathrm{A}_{1}(100 \%)$ \\
& Initial & Pulp & $\mathrm{A}_{1}(100 \%)$ \\
& & Peel & $\mathrm{A}_{1}(50 \%), \mathrm{B}_{1}(50 \%)$ \\
& Middle & Pulp & $\mathrm{A}_{1}(66.6 \%), \mathrm{B}_{1}(33.3 \%)$ \\
& Peel & $\mathrm{B}_{1}(100 \%)$ \\
& Late & $\mathrm{B}_{1}(100 \%)$ \\
\hline
\end{tabular}

Table 3: Comparison of morphological characteristics of bacterial isolates obtained from three stages of symptom development when cultured on Nutrient Agar and Crystal Violet Pectate (CVP) medium at $30^{\circ} \mathrm{C}$ for $48 \mathrm{~h}$.

\begin{tabular}{llllll}
\hline Isolate & $\begin{array}{l}\text { Colony morphology on } \\
\text { NA medium }\end{array}$ & $\begin{array}{l}\text { Pectolytic ability on } \\
\text { CVP medium }\end{array}$ & $\begin{array}{l}\text { Cell } \\
\text { shape }\end{array}$ & $\begin{array}{l}\text { Gram } \\
\text { Status }\end{array}$ & $\begin{array}{l}\mathbf{3 \%} \text { Tost } \\
\text { TeH }\end{array}$ \\
\hline $\mathrm{A}_{1}$ & $\begin{array}{l}\text { white, small, circular, flat, } \\
\text { opaque, smooth }\end{array}$ & No pit formation & $\operatorname{rod}$ & - & + \\
$\mathrm{B}_{1}$ & $\begin{array}{l}\text { dull white, large, circular } \\
\text { opaque, convex, slimy }\end{array}$ & No pit formation & $\operatorname{rod}$ & - & + \\
$\mathrm{C}_{1}$ & $\begin{array}{l}\text { yellowish white gliding } \\
\text { type colony }\end{array}$ & No pit formation & rod & - & + \\
\hline
\end{tabular}

$(+)$ formed a slimy thread, (-) Gram negative

Pectolytic bacteria form characteristic cavities in crystal violet pectate (CVP) medium due to their ability to metabolize pectin and CVP medium is used to isolate taxa belonging to different species of the genera Pectobacterium and Dickeya present in environmental samples (He'lias et al., 2012). In the present study, even though, the three bacterial isolates reported the Gram negative status and showed rod shaped cells, they did not form characteristic pits on CVP medium which is done by pectolytic bacteria. He'lias et al. (2012) reported that the success of the cavity formation by pectolytic bacteria depends on the pectin source in the medium used. Therefore, lack of cavity formation observed in the present study could be due to the unavailability of the correct pectin source in the medium used. Moreover, the three bacterial isolates when cultured on NA medium did not produce grey coloured colonies as Dickeya zeae, the causal organism of soft rot of banana reported in Columbia, Ivory Coast, Panama, several Caribbean islands and China (Zhang et al. 2014).

\section{Confirmation of Pathogenicity}

From twelve to fourteen days after inoculation, only the bacterial isolate $A_{1}$ which was inoculated to pulp of Cavendish banana, developed initial symptoms similar to the ones showed by the original disease samples (Figure 5a). 
(a)

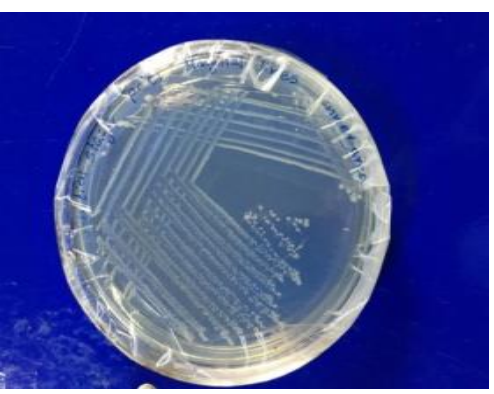

(d)

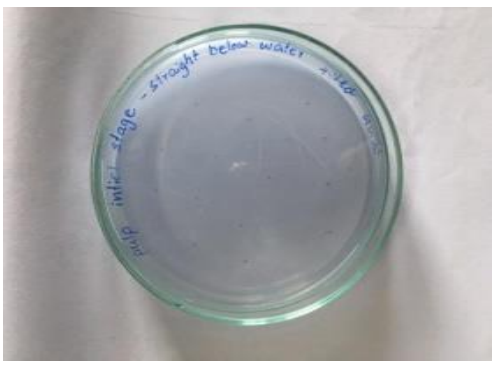

(b)

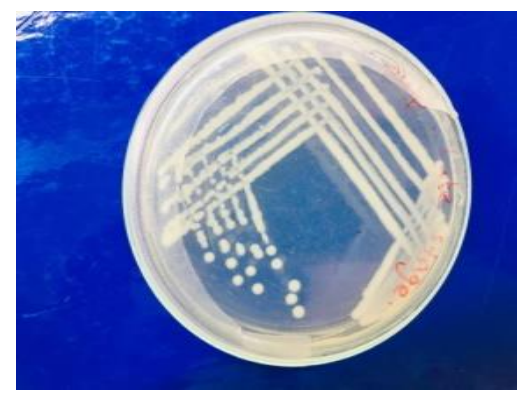

(e)

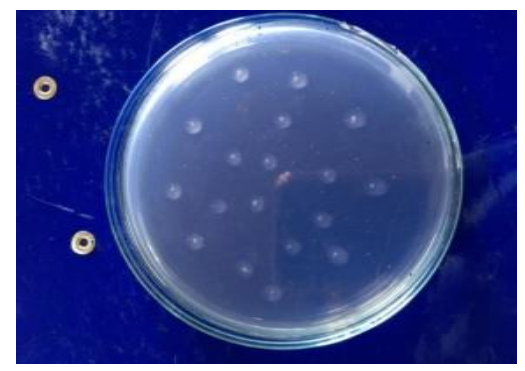

(c)

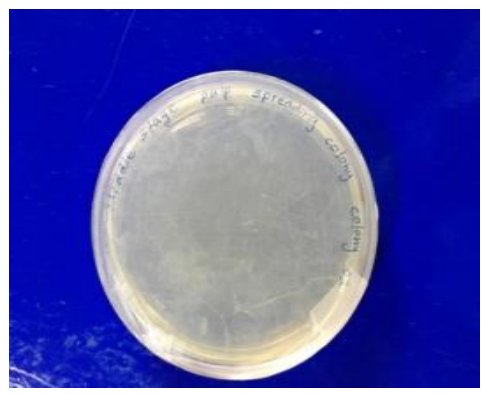

(f)

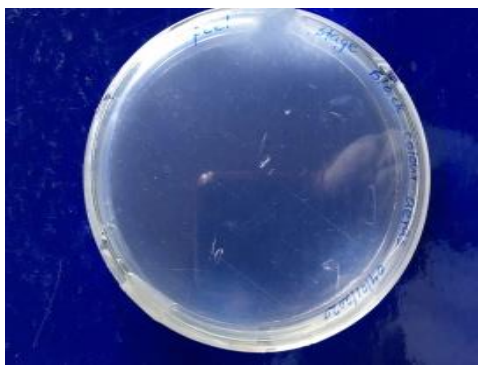

Figure 4: Colony morphology of $A_{1}, B_{1}$ and $C_{1}$ isolates on NA and CVP media incubated for $48 \mathrm{~h}$ at $3^{\circ} \mathrm{C} A_{1}$ isolate on NA (a) $B_{1}$ isolate on NA (b) $C_{1}$ isolate on NA (c) $A_{1}$ isolate on CVP (d) $B_{1}$ isolate on CVP (e) $\mathrm{C}_{1}$ isolate on CVP (f).

(a)

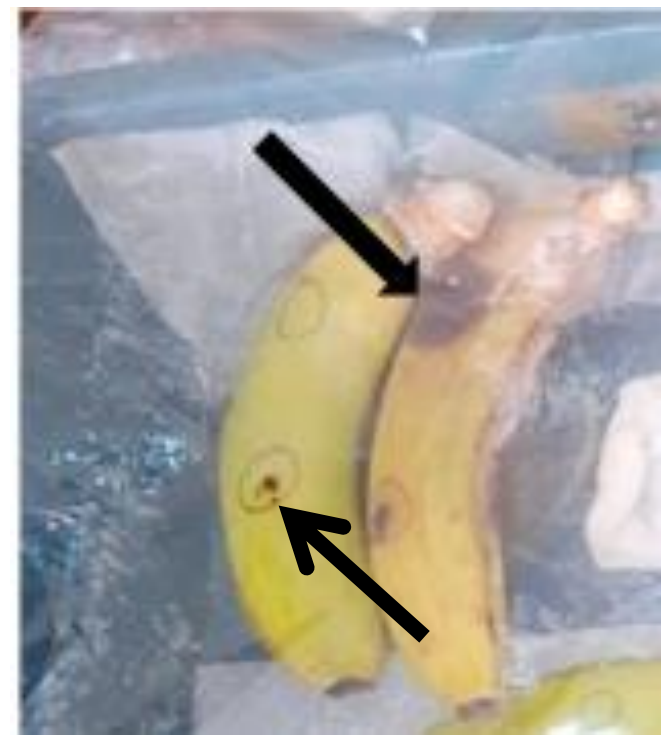

(b)

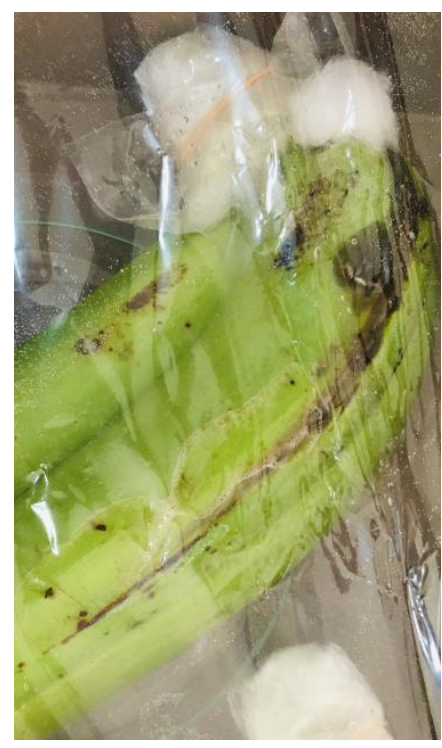

Figure 5: Initial stage symptoms (i.e. Black coloured rotten area/greasy patch (shown by black coloured arrow)) developed on Cavendish banana fingers (a) and on variety Anamalu (b) inoculated with bacterial isolate $A_{1}$ by pulp inoculation (respectively, 14 days and 2 days after inoculation). 
However, other two bacterial isolates (i.e. $\mathrm{B}_{1}$ and $\mathrm{C}_{1}$ ) did not develop symptoms on pulp-inoculated banana. Further, $A_{1}, B_{1}$ and $C_{1}$ banana under peelinoculation and the fruits under control treatment did not develop symptoms. Re-isolations done from banana fingers which gave positive symptoms inoculated with isolate $A_{1}$ resulted in bacterial colonies which were morphologically similar to isolate $A_{1}$. Therefore, it is evident that bacterial isolate $A_{1}$ is responsible for development of the finger rot disease.

\section{Symptom Development on Banana Variety Anamalu}

Variety Anamalu developed the initial symptoms (i.e. black-coloured lesion/greasy patch development) of finger rot disease, 2 days after inoculation by the pulp-inoculation method (Figure 5b). It indicated that cross infection ability of isolate $\mathrm{A}_{1}$ (D. dadantii) on other banana varieties with AAA genome and shows a variation in terms of disease severity (i.e. days taken to develop symptoms). Wide host range and variation of virulence and diverse phenotypic features are well documented for many Dickeya strains isolated from different host plants (Zhang et al., 2014).

\section{Molecular Identification}

Table 4 summarizes the DNA homology results obtained for bacterial isolate $A_{1}$ which was isolated from the finger rot at initial stage and re-isolated from the Cavendish banana fingers with developed symptoms after pulp-inoculation. Accordingly, bacterial isolate $A_{1}$, confirmed to cause finger rot of banana was identified as Dickeya dadantii through molecular methods.

Dickeya sp., formerly known as Erwinia chrysanthemi and Pectobacterium chrysanthemi have a wide host range and induce soft rot on different plants species (Ma et al., 2007). Among them, D. zeae has been reported to cause soft rot of banana in Columbia, Ivory Coast, Panama, several Caribbean islands (Samson et al., 2005) and in China (Zhang et al., 2014). Symptoms of the soft rot caused by $D$. zeae in China included leaf wilting, collapse of pseudostems, and unusual odour. Another bacterial soft rot disease of banana, named as sheath rot disease which is different to the soft rot caused by D. zeae has been reported from China. Symptoms of sheath rot disease of banana include folding and bending of the sheath, drooping of the leaves, gradual browning and rotting of the entire leaf sheath and presence of longitudinal crack along the pseudostem of the infected plants and the causal organism has been identified as $D$. dadantii (Liu et al., 2016). In addition, D. dieffenbachiae and D. paradisiaca can infect banana and cause soft rot (Samson et al., 2005). Based on the complex nature of soft rots in banana caused by a diverse group of pectolytic bacteria, it is necessary to identify the causal pathogen through a polyphasic approach which includes conventional and molecular identification methods and also by confirming the pathogenicity through standard Koch's rules.

Table 4: Details on DNA homology search results given by the bacterial isolate A1, which was isolated from the initial stage of symptom development and re-isolated from the symptomdeveloped fruits after artificial inoculation.

\begin{tabular}{llcccc}
\hline \multicolumn{1}{c}{ Sample details } & $\begin{array}{c}\text { Description of } \\
\text { best homologue }\end{array}$ & $\begin{array}{c}\text { Query } \\
\text { cover } \\
\text { (\%) }\end{array}$ & $\begin{array}{c}\text { E } \\
\text { value }\end{array}$ & $\begin{array}{c}\text { \% } \\
\text { identity }\end{array}$ & $\begin{array}{c}\text { Accession } \\
\text { number of the } \\
\text { best homologue }\end{array}$ \\
\hline $\begin{array}{l}\text { Bacterial isolate A1 from } \\
\text { initial stage of symptom } \\
\text { development }\end{array}$ & $\begin{array}{l}\text { Dickeya dadantii } \\
\text { 3937 complete } \\
\text { genome }\end{array}$ & 100 & 0.0 & 90.38 & CP002038.1 \\
$\begin{array}{l}\text { Bacterial isolate A1 re- } \\
\text { isolated from pulp- } \\
\text { inoculated fruits at initial } \\
\text { stage of symptom }\end{array}$ & $\begin{array}{l}\text { Dickeya dadantii } \\
\text { 3937 complete } \\
\text { genome }\end{array}$ & 99 & 0.0 & 95.24 & CP002038.1 \\
$\begin{array}{l}\text { Bacterial isolate B } 1 \text { isolated } \\
\text { from the symptoms at } \\
\text { middle and late stages }\end{array}$ & $\begin{array}{l}\text { Klebsiella veriicola } \\
\text { strain S9 16S } \\
\text { ribosomal RNA } \\
\text { gene }\end{array}$ & 93 & 0.00 & 92.71 & MH578615.1 \\
\hline
\end{tabular}


In the present study, bacterial isolate $\mathrm{B}_{1}$ has been identified as Klebsiella variicola by molecular methods. A soft rot of banana showing symptoms of yellow-brown, water-soaked spots on petioles of lower leaves at the initial stage and then extend gradually along the petiole in an irregular shape has been reported from China (Fan et al., 2015). It also causes rotting of the pseudostem and necrosis of vascular bundles. However, in the present study, $\mathrm{B}_{1}$ isolate, when inoculated to healthy Cavendish fruits, did not develop symptoms.

According to Souza et al. (2013), K. variicola has been reported as an endophyte in banana plants. Therefore, it is possible to hypothesize that isolate $B_{1}$ could dwell as an endophyte in banana without harming it through disease development and could perform an endophytic infection/secondary infection on tissues which are primarily infected with isolate $\mathrm{A}_{1}$ (i.e. D. dadantii).

As shown in Table 2, at the late stage of symptom development, $A_{1}$ isolate could not be recovered from the inoculated fruits, instead isolate $\mathrm{B}_{1}$ was obtained. $K$. variicola has been identified as a bacterium with antagonistic properties and it could be a reason for not having other bacterial isolates in the presence of $K$. variicola.

\section{Phylogenetic relationship}

Isolate $A_{1}$, the strain of $D$. dadantii which was identified as the causal organisms of finger rot disease of the present study formed a separate group with $D$. dadantii 3937, indicating the closer genetic relationships of the two organisms. $D$. dadantii 3937 has been initially isolated from Bacterial Blight of Saintpaulia ionantha (African violet) in Florida, USA (Knauss and Miller, 1974) and reported as Gram negative bacterium producing white coloured colonies (which agrees with our findings). When the bacterium was inoculated on to leaf cuttings of $S$. ionantha, initially black, greasy coloured lesions were observed which is on par with our observations on inoculated banana fingers. Two days after inoculation the inoculated petioles were soft, brownish-black and separated easily from the

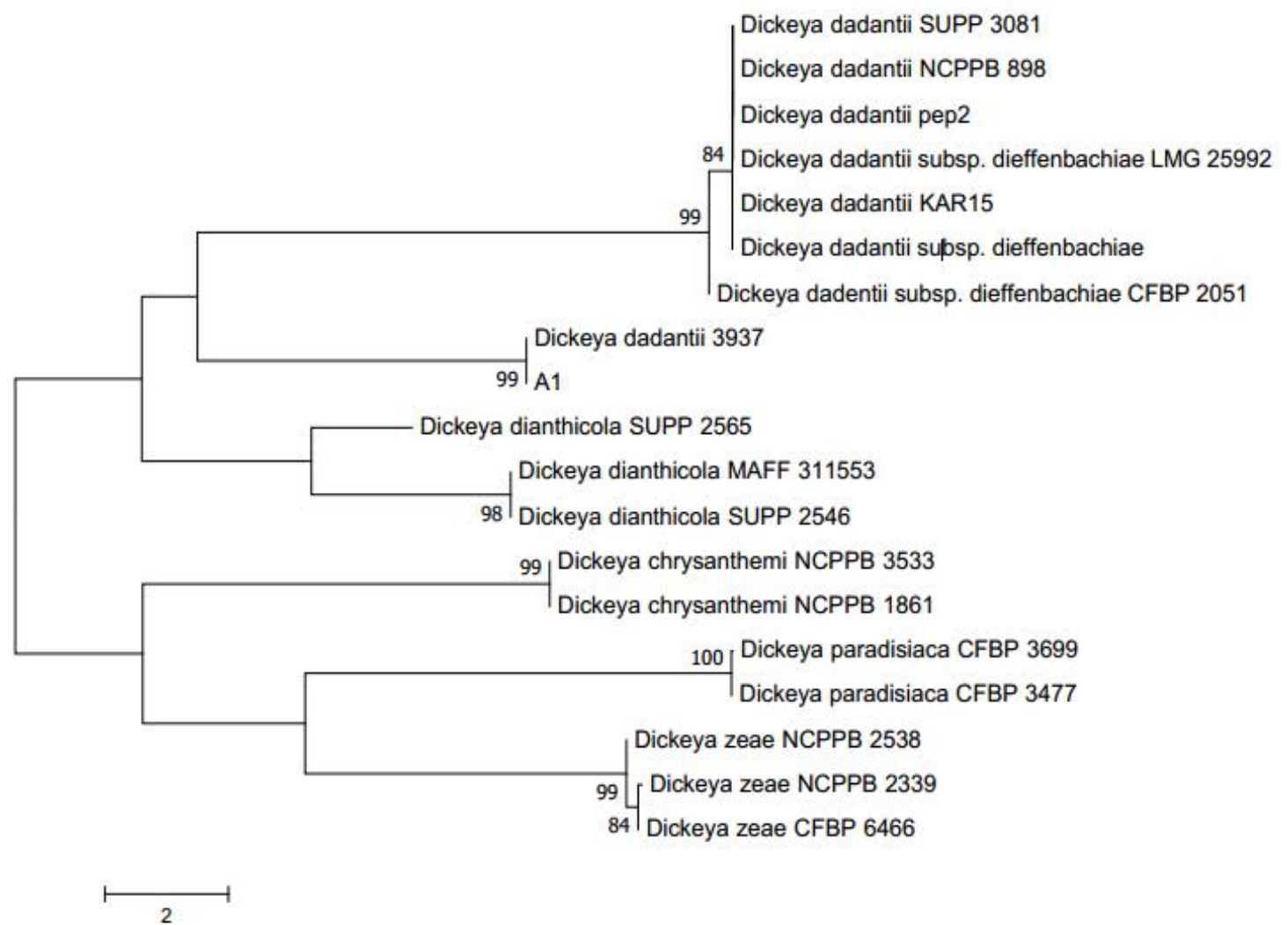

Figure 6: Phylogenetic analysis of bacterial isolate $A_{1}$ with related Dickeya spp. based on 16s rRNA gene sequence 
leaves (Knauss and Miller, 1974). The pathogen has been isolated from soft rot and wilt of a various range of plants, such as maize, pineapple, banana, rice, tobacco, tomato, Brachiaria ruziziensis and Chrysanthemum morifolium, as well as from water (https://www.uniprot.org /proteomes/ UP00000 6859).

\section{CONCLUSION}

The study identified the causal agent of banana wet finger rot as a strain of $D$. dadantii by conventional

\section{REFERENCES}

Chen, W.P. and Kuo, T.T. (1993). A simple and rapid method for the preparation of gram-negative bacterial genomic DNA: Nucleic Acids Research. 21(9), 2260. doi: 10.1093/nar/21.9.2260.

EDBSL (2019). Cyber extension: Industry capable report- Fresh fruits and vegetable [on line]. [Accessed on December 2019]. Available at https://www.srilankabusiness.com/publicatio ns/industry-capability-reports/fresh fruits and vegetable.htm.

Fan, H.C., Zeng, L., Yang, P.W., Guo, Z.X. and Bai, T.T. (2015). First report of banana soft rot caused by Klebsiella variicola in China: Plant Disease. 100(2), 517-517. doi.org/10.1094/PDIS-05-150586-PDN.

Frank, J.A., Reich, C.I., Sharma, S., Weisbaum, J.S., Wilson, B.A., and Olsen, G.J. (2008). Critical evaluation of two primers commonly used for amplification of bacterial 16S rRNA genes: Applied and Environmental Microbiology. 74(8), 2461-2470. DOI: 10.1128/AEM.0227207.

Hassanzadeh, N. (1990). Characterization of a new soft rot Erwinia to banana in Iran: Iranian Journal of Plant Pathology. 26, 1-4.

Hathurusinghe, C.P., Vidanapathirana, R., Rambukwella, R.O.S.H.I.N.I. and Somarathne, T.G. (2012). Study on value chain of pineapple and banana in Sri Lanka. 145, 4-17.

He'lias, V., Hamon,P., Huchet,E., Wolf,J.V.D. and Andrivon, D. (2012). Two new effective semi selective crystal violet pectate media for isolation Pectobacterium and Dickeya: Plant Pathology. 61(2), 339-345. doi.org/10.1111/ j.1365-3059.2011.02508.x. and molecular biological identification methods and phylogenetic analysis. This is the first report in Sri Lanka on isolation, identification and confirmation of pathogenicity of the causal agent of banana wet finger rot reported in commercial cultivations in Sri Lanka.

\section{ACKNOWLEDGEMENTS}

Research and logistical coordination of $\mathrm{Mr}$. T.M.M.S. Thennakoon of Dole Lanka PVT (LTD) is acknowledged.

Knauss, J.F. and Miller, J.W., (1974). Bacterial blight of Saintpaulia ionantha caused by Erwinia chrysanthemi. Phytopathology. 1046-1047. DOI: 10.1094/Phyto-64-1046.

Kumar, S., Stecher, G. and Tamura, K. (2016). MEGA7 molecular evolutionary genetics analysis version 7.0 for bigger datasets: Molecular Biology and Evolution. 33(7), 18701874. DOI: $10.1093 / \mathrm{molbev} / \mathrm{msw} 054$.

Lin, B.R., Shen, H.F., Pu, X.M., Tian, X.S., Zhao, W.J., Zhu, S.F. and Dong, M.M. (2010). First report of a soft rot of banana in mainland China caused by a Dickeya sp. (Pectobacterium chrysanthemi). Plant Disease. 94(5), 640-640. doi.org/10.1094/PDIS-94-5-0640C.

Liu, Q., Xiao, W., Wu, Z., Li, S., Yuan, Y. and Li, H. (2016). Identification of Dickeya dadantii as a causal agent of banana bacterial sheath rot in China: Journal of Plant Pathology. 503-510. http://www.jstor.org/stable/44280493.

Ma, B., Hibbing, M.E., Kim, H.S., Reedy, R.M., Yedidia, I., Breuer, J., Breuer, J., Glasner, J.D., Perna, N.T., Kelman, A. and Charkowski, A.O. (2007). Host range and molecular phylogenies of the soft rot enterobacterial genera Pectobacterium and Dickeya: Phytopathology. 97(9), 150-1163. DOI: 10.1094/PHYT0-97-9-1150.

Perera, S., Rambodagedara, M. and Wijesinghe, R. (2015). Fruit and Vegetable Export Growth Instability and Diversification: Hector Kobbekaduwa Agrarian Research and Training Institute. 173, 28-45.

Samson, R., Legendre, J.B., Christen, R., Fischer-Le Saux, M., Achouak, W. and Gardan, L. (2005). Transfer of Pectobacterium chrysanthemi (Burkholder et al., 1953) Brenner et al., 1973 and Brenneria paradisiaca to the genus Dickeya gen. nov. as Dickeya chrysanthemi comb. nov. 
and Dickeya paradisiaca comb. nov. and delineation of four novel species, Dickeya dadantii sp. nov., Dickeya dianthicola sp. nov., Dickeya dieffenbachiae sp. nov. and Dickeya zeae sp. nov.: International Journal of Systematic and Evolutionary Microbiology. 55, 1415-1427. DOI: 10.1099/ijs.0.02791-0.

Snehalatharani, A. and Khan, A.N.A. (2010). Biochemical and physiological characterisation of Erwinia species causing tip-over disease of banana. Archives of Phytopathology and Plant Protection. 43(11), 1072-1080. doi.org/10. 1080/03235400802285422.
Souza, S.A., Xavier, A.A., Costa, M.R., Cardoso, A., Pereira, M.C. and Nietsche, S. (2013). Endophytic bacterial diversity in banana'Prata Anã'(Musa spp.) roots. Genetics and Molecular Biology. 36(2), 252-264. DOI.10.1590/S141547572013000200016 .

Zhang, J., Shen, H., Pu, X., Lin, B. and Hu, J. (2014). Identification of Dickeya zeae as a causal agent of bacterial soft rot in banana in China: Plant Disease. 98(4), 436-442. doi.org/10.1094/ PDIS-07-13-0711-RE. 